\title{
A Conceptual Research Paper on Tax Compliance and Its Relationships
}

\author{
K. G. Asela Gamini Bandara ${ }^{1} \&$ W. M. R. B. Weerasooriya ${ }^{2}$ \\ ${ }^{1}$ MBA Student, University of Rajarata, Mihintale, Sri Lanka \\ ${ }^{2}$ Senior Lecturer, University of Rajarata, Mihintale, Sri Lanka \\ Correspondence: K. G. Asela Gamini Bandara, MBA Student, University of Rajarata, Mihintale, Sri Lanka. \\ E-mail: aselabandara214@ymail.com
}

Received: July 10, 2019

doi:10.5539/ijbm.v14n10p134

\author{
Accepted: August 13, 2019 \\ Online Published: September 5, 2019 \\ URL: https://doi.org/10.5539/ijbm.v14n10p134
}

\begin{abstract}
This paper aims to elaborate the different views held by various scholars in connection with tax compliance and its relationships with other variables, which will become more useful for future researchers when they are planning to undertake any particular research in relation to this area in addition, this also plays a critical role when gaining new knowledge as well as broaden the existing knowledge in relation to this particular area. Hence, it reviews the previous literature brought by the previous scholars to identify the relevant concepts and their importance to the present context, therefore, the researcher was studied around 250 research articles, which were published by various organizations and the other different authors. Finally, around 100 articles were drawn and reviewed to ascertain relevant concepts and their validity to the present context in Sri Lanka. Therefore, the conceptual ideas brought from this review paper will set a new direction for future research that will help to understand the significances of these conceptual ideas. If it makes sense in the future studies, then these concepts will apply to different practical situations in Sri Lanka as well as globally.
\end{abstract}

Keywords: tax compliance, tax rate, tax information, tax compliance cost, tax legal framework

\section{Introduction}

Tax compliance has been defined in various ways by various scholars. According to Ayuba, Saad and Ariffin, (2016) they defined tax compliance as taxpayers adhere to relevant tax laws and regulations, however, according to Marziana, Norkhazimah and Mohmad, (2010) they highlighted tax compliance as the degree to which taxpayer adhere with tax laws and regulations in their own country. Furthermore, according to Alabede, Zaimah and Kamil (2011) highlighted that developing countries still featuring a low level of tax compliance due to the many obstacles prevailing for voluntary tax compliance. One of the major reasons is due to tax audits and other enforcement measures. Turning to (Lediga, 2018) revealed that there are around 300,000 tax-evading firms in South Africa but they continued to report lower income than firms that had always been in the tax net. According to the facts disclosed by the Minister of Finance in Indonesia, it was revealed that the lowest tax compliance was seen in Small and Medium Enterprises (SMEs) (Rachman, 2017) and this was further revealed that only 397,000 SMEs who paid taxes from the total of 59 million SMEs or just around 0.7\% of SMEs Sawitri, (2017b). According to (Chebusit, 2014) highlighted that many governments in the world have been taking enough tax administration measures such as penalties, tax audits, etc in order to ensure tax enforcements but researchers recently found that even though several states have already taken several administrative reforms but levels of tax collected has remained quite low due to low level of tax compliance. 


\subsection{Tax Compliance Trends in Sri Lanka}

Table 1. Corporate Income Tax Return Compliance 2011/2012 to 2015/2016

\begin{tabular}{lll}
\hline Year of Assessment & Compliance on the due date & Compliance within one month from the due date \\
\hline $2011 / 2012$ & $56 \%$ & $60 \%$ \\
$2012 / 2013$ & $56 \%$ & $70 \%$ \\
$2013 / 2014$ & $53 \%$ & $61 \%$ \\
$2014 / 2015$ & $52 \%$ & $58 \%$ \\
$2015 / 2016$ & $30 \%$ & $46 \%$ \\
\hline
\end{tabular}

According to the table 1, In the case of corporate sector income tax compliance in the year of assessment $2015 / 2016$, it was $30 \%$ on the due date and $46 \%$ within one month from the due date and further $48 \%$ within two months from the due date.

Table 2. Return compliance on other taxes

\begin{tabular}{llll}
\hline Year & VAT & ESC & NBT \\
\hline 2014 & $49 \%$ & $71 \%$ & $84 \%$ \\
2015 & $65 \%$ & $68 \%$ & $86 \%$ \\
2016 & $71 \%$ & $79 \%$ & $31 \%$ \\
\hline
\end{tabular}

Note. VAT=Value added tax; $\mathrm{ESC}=$ Economic service charge, $\mathrm{NBT}=$ Nation building tax.

As shown in the table 2, the return compliance rate of all other taxes has been almost consistent. However, a considerable decline in the rate is seen in NBT in the concerned year. During the year 75,811 new taxpayers were registered with NBT under the field survey carried out by the IRD. Non familiarizing of such taxpayers in submitting returns would be a reason for this decline.

\section{Literature Review}

Under this heading, the researcher discuss the various theories presented by the various scholars in relation to the tax compliance as well as the various views already expressed by the various organizations and the other researchers to exhibit the relationships between the tax compliance as a dependent variable and the other variables such as tax rate, tax information, taxpayers' attitudes, legal framework and the cost of tax compliance as independent variables.

\subsection{Theories Relating to Tax Compliance}

The following theories about tax compliance have been developed by various scholars to show how various conditions (Ex: people's trust towards the government/quality of goods and services provided by the government to its people) enhance the level of tax compliance. These theories can be explained in brief as follows.

\subsubsection{Optimal Tax Theory}

The basic feature of this theory is that the government likes to collect a given amount through taxation. Emanuele (2012) illustrates that this theory includes several models that concentrate on the characteristic of a tax system. Further, these models aim to achieve an equilibrium level of taxes raised by the government to achieve their revenue targets. In addition to that, these models are formulated to meet certain principles of the good tax system such as equity, stability, flexibility and transparency, etc (Emanuele et al., 2012).

\subsubsection{Political Legitimacy Theory}

This theory illustrates that tax compliance is largely influenced by the extent to which their citizens trust their government (Tyler, 2006) and (Kirchler,2008). Further, according to Persson (2008) emphasized that building national identity is more successful than they become major opponents of politics.

\subsubsection{The Tax Moral Theory}

The tax morale theory was first developed by German scholars well known as Cologne school of tax psychology. Tax morale which is an individual factor that motivates a person to comply with his or her tax obligations. Many studies have found out that tax evasion can be attributed to tax morale (Mocetti, Vol 18 No. 6). This theory further stated that taxpayers are more likely to comply with tax obligations if their friends, relatives and 
acquaintances comply with these obligations. Also, taxpayers will evade taxes if they feel that other people are getting away with tax evasion. That means if a society concentrates on tax evasion, such a society would encourage tax evasion (Waweru, 2004).

\subsubsection{Theory of Planned Behavior}

The theory of planned behavior is an important theory that presents within the scope of social psychology and tries to explain human behaviors. This theory was developed by (Ajzen, 1991) and it is just the improved form of the Theory of Reason Action suggested by (Ajzen \& Fishbein, 1991) to explain conscious behaviors. According to this theory, behaviors of the individuals within the society are under the influence of several factors, originate from certain reasons and emerge in a planned way (Erten, 2002). Nevertheless, the ability to perform a particular behavior depends on the fact that the individual has a purpose towards that behavior.

\subsubsection{Fiscal Exchange Theory}

This illustrates that the government can enhance the level of tax compliance by providing goods and services to its people more efficiently and effectively (Cowell \& Gordon, 1988), (Levi, 1988), (Tilly, 1992) and (Moore, 2004). Further, which also provides a good link between the taxpayers and the government (Moore et al., 2004). Therefore, it is more justifiable to assume that taxpayers' behavior is influenced by either their level of satisfaction or level of dissatisfaction with the provision of public goods and the services.

\subsubsection{The Allingham and Sandmo Theory (AS Theory)}

This theory was developed by Allingham and Sandmo. According to (Sandmo, 1972) The AS theory expresses that the government tries to prevent tax evasion through undertaking a series of actions such as putting extra penalties, undertaking tax audits etc. A taxpayer will decide to evade his or her tax obligations when he or she feels that the cost of evading tax is too low. Taxpayers would also evade tax when he or she feels that the cost of compliance is high

\subsubsection{Economic Deterrence Theory}

Which states that taxpayers' behavior is influenced by a range of factors such as tax rate, penalties etc. According to (Becker, 1968) which implies that when the strength of the tax audits and the penalties are high then, very few people will try to avoid taxes. On the other hand, when the strength of the tax audits are less and the penalties are low then, expected to evade the taxes is very high. Further, this theory is highly adopted by tax administrators when developing suitable strategies.

\subsubsection{Theory of Crime}

The theory of crime states that people are rational actors who behave in a manner that will maximize their expected utility. (Becker et al., 1968) argued that authorities needed to and appropriately balances between detection of non-compliers and measures to the point where non-compliance becomes irrational In fact, research has shown that the use of threat and legal coercion, can produce negative behavior; these actions are more likely to result in further non-compliance (Murphy and Harris,2007), creative compliance (McBarnet, 2003), criminal behavior or opposition (Fehr \& Rokenbach, 2003).

\subsection{Previous Empirical Evidence on Relationships between Tax Compliance and Other Variables}

The researcher found out empirical evidence from various types of sources to establish a relationship between each of the following independent variables and the dependent variable. These relationships can be either positive or negative which depends on the situation. The researcher presents the empirical evidence under the separate heading as follows.

\subsubsection{Relationship between tax rate and the tax compliance}

According to (Clotfelter, 1983) who took as a measure of tax compliance the logarithm of evaded income in three different taxpayer groups, according to the source of their income. Moreover, he included variables such as age, marital status, the fiscal residence of taxpayers and other sources of income. Three categories of taxpayers were considered, the variable marginal tax rate positively affected the dependent evaded income variable. Specifically, elasticity values ranged from 0.515 to 0.844 . For example, if the marginal tax rate is $40 \%$, a drop of $10 \%$ of this percentage results in an expected decrease of evasion which can vary between $5 \%$ and $8 \%$. Undoubtedly, these results are consistent with the intuition that higher tax rates will encourage tax evasion. Some studies suggest that high tax rates encourage tax evasion. The idea is that high tax rates increase the tax burden and, hence, lower the disposable income of the taxpayer (Chipeta, 2002) However, the level of the tax rate may not be the only factor influencing people's decisions about paying taxes. There is an effect on the tax system as a whole. If, for example, the tax rate on corporate profits is relatively low, but individuals are facing a high tax rate 
on their income, then they have to bear huge tax liability, which is not fair and as a result of that taxpayers are not willing to declare their total income. Therefore, tax rates and the overall structure of the tax system have a significant effect in determining whether to evade their tax liabilities or not. Further, according to Atawodi and Ojeka (2012), they found that high tax rates, as well as the complex filling procedures, are the major external determinants of tax non-compliance.

According to Sapiei and Kasipillai (2013), they highlighted the tax rate and penalty structure determine the financial value of tax compliance, which leads to the taxpayers' compliance behaviors. In addition to that, taxpayer judge the cost that occurs when remained as a defaulter, penalties occurred for fraud and benefits of not paying taxes, and determine not to pay taxes if the benefit of non-compliance exceed the costs (Walsh, 2012). (Ali,2018) revealed that the tax rate has a positive and significant influence on income tax compliance. (Yunus, 2017), revealed that the rate of tax penalties has a positive effect on tax compliance behavior. Mas' ul (2014) found that there is a significant negative correlation between tax rate and tax compliance. (Anderhub, 2001) found that increased tax rate discouraged tax evasion leads to a positive relationship between them. Friedland, (1978), Collins and Plumlee, (1991) found that a low level of tax compliance occurs at higher tax rates that means having a negative relationship between them.

\subsubsection{Relationship between tax information and tax compliance}

According to survey findings, taxpayers that are less educated are consequently less exposed to information about tax compliance and the relevant regulations covering tax. As a result, they require constant assistance. For example, Kenya has been implementing a continuous tax education for taxpayers and children as future taxpayers (Palil, 2010). In addition to tax education, knowledge about tax laws also plays a major role in determining taxpayers' compliance behavior. According to (Carroll, 2011) on taxation among SME's in the informal sector in Ghana found out that despite the fact that more than half (65 percent) of the SME's surveyed were aware that they have to pay taxes, more than half were not well informed as to why they paid tax and more than 50 percent did not enjoy the benefits of paying it. However, solely relying on tax education cannot ensure continued tax compliance. The findings of this study -(Carroll et al., 2011) are in accordance with the research of (Nugroho and Zulaikha, 2012) and (Munari,2005), discussing an economic class of a society; for example, this will increasingly determine who will get much and various information about taxation knowledge and all the consequences in the society. In such circumstances, the public is given the option to pay taxes on time to avoid fines and it is one form of public awareness of the importance of paying taxes for the construction of the nation. This study proves that the contribution of knowledge and understanding of tax regulation leads to better compliance in society.

Krause (2000) and Santoso (2008) argued that the more people understand the tax laws, the higher the state revenue obtained from the tax sector because the public realizes the importance of taxes to the state. This study proves the awareness of taxpayers in making tax payments and reports has demonstrated the formal compliance that is, making tax payments and reports right on time. Further, according to (Saad, 2003) found that demand for tax agents increased rapidly in Malaysia due to the lack of technical knowledge among the taxpayers. According to a recently conducted Country Study for Sri Lanka by the (Institute of Policy Studies [IPS], 2015), it has been revealed several important facts relating to the tax compliance decision among the SMEs. Since the majority of SMEs are less concern about the importance of being tax-compliant, this study suggests conducting several tax awareness programs and workshops to increase their level of voluntary tax compliance. (Andreoni, J, and Errard, $B, 1998$ ) done tax research which has shown that the degree of information is an important factor in the behavior of taxpayers and how it influences tax evasion. Less-educated taxpayers are not much concern about tax compliance information and are more prone to tax evasion. Some taxpayers find the complexity of tax information cause too difficult to understand than others. This complexity may lead to unintentional noncompliance if taxpayers have problems in filling of tax returns. (Troiano, 2017) mentioned that the sharing of tax information across governments in the United States (federal governments, state governments) has been found to improve compliance. (Beesoon, 2016) and (Geletaw,2017) found that tax knowledge and education has a negative and significant impact on tax compliance. (Bernadette, 2010) concluded on the lack of knowledge and understanding of taxation by small business owners who are less likely to comply with the tax payment. Laksono and Ardiyanto (2007), Kariyoto, (2010), Pratama, (2012) and Sjursen, (2014) who agreed that there is an influence of tax knowledge and understanding on the compliance in carrying out tax obligations. Mckerchar (1995) and Loo (2008) discovered that technical knowledge shortfall leads to unintentional tax non-compliance among the taxpayers. 


\subsubsection{Relationship between Taxpayers' Attitudes and Tax Compliance}

In a study of tax morale in 17 Latin American countries, (Torgler,2005) found that over $46 \%$ of the respondents perceived a high tax burden to be the reason why people did not pay taxes; " because the taxes are too high" was the most frequently mentioned reason. Some studies (Alm, Jackson, \& Mckee, 1992) that have been developed and are outside the period of research but still important in this field showed that participants faced tax rates varying from $10 \%, 30 \%$, and $50 \%$ and fines amounting to double or triple the amount of evaded taxes. The findings showed that income and tax rates were the biggest determinants of non -compliance attitudes and tax evasion amongst participants. The higher the tax rate and the lower the income, the participants' noncompliance attitudes were higher and were evading paying taxes. Most studies found that high tax burdens hurt tax compliance attitudes in both developed and developing countries. According to (Garboua, 2006) who have surveyed in Romania while doing a survey they asked questions about the taxation system in Romania, the majority of the taxpayers mentioned that fairness is the most important issue rather than tax burden, tax rate and efficiency of government expenditures. A majority indicated that a high level of fairness leads to a high level of tax compliance. The study further discovered that the $50 \%$ tax rate is the maximum level taxpayers accept. However, a survey done by (Porschke \& Witte, 2002) found that a $30 \%$ tax rate appears to be somewhat justifiable.

According to Asia Pacific Journal of Research (2015), it has been published the findings relating to the study done in Sri Lanka by M.B.M. Amjath relating to the taxpayers' attitudes towards the income tax system in Sri Lanka. Some of the findings are as follows,

- $38 \%$ of respondents mentioned positive views that tax authority makes tax enforcement.

- $42 \%$ of respondents preferred that there was fear of tax audit and prosecution.

$-63 \%$ of respondents agreed that tax evasion is ethical if it is supported by unfair tax law.

$-57 \%$ of the respondents agreed that tax evasion is ethical if the tax system is unfair.

$-52 \%$ of the respondents who were agreed that tax evasion is ethical if the tax rates are too high.

- $50 \%$ of the respondents expressed their negative views that tax evasion is ethical if the probability of getting caught is low.

$-54 \%$ of the respondents agreed that tax evasion is ethical even if tax rates are not too high.

$-54 \%$ of the respondents expressed positive views that tax evasion is ethical if everyone is doing it.

$-71 \%$ of the respondents expressed their negative views that tax evasion is ethical if the taxpayer cannot afford to pay.

Under the same survey, the researcher wanted to gain views from various respondents about the overall tax system in Sri Lanka.

$-51.5 \%$ of the respondents expressed that the present tax system is justifiable

- $48.5 \%$ of the respondents expressed that the tax system was unjustifiable.

According to International Journal of Arts and Commerce (2016), it has been published the findings relating to the study done in Colombo city area by one of the Ph.D. student, whose name was Damayanthi Jayawardane relating to the taxpayers' attitudes in the Colombo city area which revealed that

- 74\% of the taxpayers indicated that the tax system in Sri Lanka is unfair with weak tax administration.

$-26 \%$ of the taxpayers indicated that the tax system is fair.

\subsubsection{Relationship between the legal framework and the tax compliance}

In South Africa, studies conducted by the economy watchdog (2015) on tax burdens on SMEs revealed that tax requirements procedures acted as stumbling blocks to tax compliance. This is because complying with taxes tended to swallow up the resources that the SMEs could devote to the more economical running of these businesses. A majority of SMEs experience their tax liability as an increasing burden since they lack enough skilled staff to handle tax compliance issues and are therefore forced to incur 'extra' tax costs. The study also noted that changes in tax policies sometimes result in an even more complex tax system. A clear finding was that elaborate tax incentive schemes that require sophisticated systems and skilled staff would often result in increased compliance costs rather than provide real tax relief. As a result, small businesses (and probably other taxpayers as well) would prefer simple cuts in tax rates and penalties if not result in tax evasion which leads to reduce the level of tax compliance. There are several studies done previously which shown that higher educated 
taxpayers understand the meaning of the tax law quite comprehensively as a result of that they comply more than the less educated taxpayers (Schmolders, 1960), ( Song \& Yarbrough, 1978) and (Spicer \& Lundstedt, 1978).

Mehari, Daniel and Pasha, (2017) revealed that procedures of tax collection and enforcement of the tax law influence positively the voluntary tax compliance behavior of taxpayers. For countries such as Australia, France, New Zealand, and the USA have already taken enough steps to simplify tax law but they had little impact on the improvement of the tax law. But actually, it did not affect the increase in tax compliance. (Kogler, 2016) revealed that any delay in responses on tax audits is far more effective in improving compliance than immediate feedback. Jayawardane and Low, (2016) found that the complexity of the tax system negatively affecting tax compliance decisions. (Nahida,2014) found that a large proportion of the compliant SMEs taxpayers mentioned the complexity of VAT law in Bangladesh, as well as the compliance cost, were the two important factors that influence the VAT non-compliance in SMEs. Marshall (1998) and Owens and Hamilton (2004) demonstrated that it is extremely hard to determine whether the taxpayers' behavior is in line with tax law. Some studies show that the complexity of tax law creates an uncertain situation in the taxpayers' minds which leads to a decrease in the tax compliance level.

\subsubsection{Relationship between the Cost of Tax Compliance and Tax Compliance}

There is a wide perception by the taxpayer that tax is a burden especially the small and medium enterprises (Vihanto, 2000) Therefore, the cost of compliance to taxation plays a key role in determining taxpayers willing to pay tax. According to the (IPS,2015), it has been revealed several important facts relating to the tax compliance decision of the Small and Medium Enterprises operating in Sri Lanka. One of the important things discovered was that most of the SMEs are not aware of the benefits and the costs of tax compliance. Further, this study uncovered that most of the SMEs are not much concern about the tax concessions offered by the government from time to time as a result of that, they are not able to enjoy the tax benefits significantly. Hence, it is suggested that it is important to keep tax expertise within the organization or outsource them from an external organization. In most cases, benefits may be exceeded the cost of maintaining such expert personal either internally or externally. From the researcher, such expert personnel may help SMEs to take tax compliance decisions at an appropriate time while saving the financial cost in terms of penalty. Small Businesses regularly incur large costs when they preparing, filing, and paying taxes in addition to the burden of tax payments. These compliance costs often deter business creation and growth in developing countries. Tax compliance cost investigations can provide useful feedback on how to reduce compliance costs and risks for small businesses. These surveys conducted in countries like South Africa, the Republic of Yemen, Ukraine, and Peru that measured the burdens on business. These surveys helped fine-tune the design of reforms to lower costs for businesses and improve their competitiveness (Coolidge, 2010). High compliance costs can result in tax avoidance, tax fraud, and prevent investment coming into the country by way of diminishing competitiveness of the country in terms of taxation attractiveness (Ojeka, 2012).

According to Eragbhe and Modugu (2015), they have surveyed to evaluate the cost of tax compliance for SMEs in Nigeria, but ultimately they found that the cost of tax compliance comprises of internal compliance cost, external compliance cost and several incidental costs including psychological cost. They also found that smaller SMEs are taxed more than the quite large SMEs, and therefore there was the existence of tax compliance costs in Nigeria. In a study carried out on tax compliance and simplifications by (Organization for Economic Cooperation and Development [OECD], 2014) established that compliance costs tend to increase with the number of taxes that an entrepreneur is subject to, the complexity of the tax rules, the frequency of submitting tax returns and the number of levels of government involved in levying and collecting taxes. This leads to SMEs avoiding the paying of taxes as it affects the business. Chebusit, Namusonge, Biraori, and Kipkoech (2014) found that there was a positive relationship between the compliance cost and tax compliance. This indicated that When an increase in compliance cost that would lead to improve tax compliance and further it agrees with Hijattulah and Pope (2008) as costs incurred by a company, but are beyond the control of its management, hence tax compliance cost is likely to affect tax compliance in the SMEs. Osebe (2013) has surveyed in the real estate sector in Kenya, the results indicated that compliance cost harmed the level of tax compliance of the real estate sector in Kenya. They believe that high compliance costs can result in tax avoidance, tax fraud, etc. Therefore, which result in a low level of tax compliance.

\section{Method and Analysis}

Under this heading, the researcher highlights the key purpose of presenting this conceptual paper as well as the methodology, which is based on the study such as population and sampling method used to identify the relevant concepts and their significance to the present context in the society. 


\subsection{Research Objectives}

The purpose of this review paper is to elaborate on the different views held by various scholars on tax compliance and its relationships with other variables to identify the different concepts and its importance to the present context in Sri Lanka.

\subsection{Methodology}

This study mainly concentrates on exhibiting the conceptual ideas held by various researchers in connection with this particular area. Hence, it reviews the previous literature brought by the previous scholars to identify the relevant concepts and their importance to the present context, therefore, the researcher was studied around 250 research articles, which were published by various organizations and the other different authors. Finally, around 100 articles were drawn and reviewed to ascertain relevant concepts and their validity to the present context in Sri Lanka.

\section{Results and Discussions}

The researcher evaluated the findings based on the two key statistical tools, which are the correlation matrix and the regression analysis and then analyze the results to establish the links between the tax compliance and the other independent variables. The results can be presented as follows in a three-line table (Refer table 3 ).

Table 3. Results of the analysis based on the relationships between tax compliance and the following independent variables

\begin{tabular}{|c|c|c|}
\hline $\begin{array}{l}\text { Independent } \\
\text { Variable }\end{array}$ & $\begin{array}{l}\text { Results based on the } \\
\text { Correlation matrix }\end{array}$ & $\begin{array}{l}\text { Results based on the } \\
\text { Regression analysis }\end{array}$ \\
\hline Tax rate & $\begin{array}{l}\text { Reveals that the Coefficient for tax rate was } .013 \text {, which } \\
\text { mean } r \text { value is less than } 0.3 \text { therefore, there is a lower } \\
\text { level of positive correlation exist between the level of tax } \\
\text { compliance and the tax rate. }\end{array}$ & $\begin{array}{l}\text { Found that the coefficient for tax rate was }-.076 \text { which } \\
\text { means when the tax rate increase by one unit, this } \\
\text { would result in the level of tax compliance is reduced } \\
\text { by (.076). So, exist a negative relationship between the } \\
\text { level of tax compliance and the tax rate. }\end{array}$ \\
\hline Tax information & $\begin{array}{l}\text { Findings reveal that the Coefficient for tax information } \\
\text { was } 0.290 \text {, which means the } r \text { value is less than } 0.3 \\
\text { therefore, there is a lower level of the positive correlation } \\
\text { between the level of tax compliance and the tax } \\
\text { information. }\end{array}$ & $\begin{array}{l}\text { Found that the Coefficient for tax information was } \\
0.021 \text {, which means when increasing the availability of } \\
\text { the tax information, which results in the level of tax } \\
\text { compliance is increased by .021, hence occur a positive } \\
\text { relationship between them. }\end{array}$ \\
\hline $\begin{array}{l}\text { Taxpayers' } \\
\text { attitudes }\end{array}$ & $\begin{array}{l}\text { Reveals that the coefficient for taxpayers' attitudes } \\
\text { is } .546 \text { which means } r \text { value is more than } 0.5 \text { hence; there } \\
\text { is a positive correlation between the level of tax } \\
\text { compliance and the taxpayers' attitudes. }\end{array}$ & $\begin{array}{l}\text { Found that coefficient for taxpayers' attitudes was } .655 \\
\text { that means when the taxpayers' attitudes towards the tax } \\
\text { system improve, which is lead to increase the level of } \\
\text { tax compliance by } .655 \text {. So, exist a positive relationship } \\
\text { between them. }\end{array}$ \\
\hline Legal framework & $\begin{array}{l}\text { Found that the coefficient for a legal framework was } \\
-.162 \text {, hence there is a negative correlation exist between } \\
\text { the level of tax compliance and the legal framework. }\end{array}$ & $\begin{array}{l}\text { Found that coefficient for the legal framework was } \\
-.209 \text { which means when tax law becomes more } \\
\text { complex to the taxpayers, then this would lead to } \\
\text { reducing the level of tax compliance by }-.209 \text { therefore, } \\
\text { exists a negative relationship between them. }\end{array}$ \\
\hline $\begin{array}{l}\text { Cost of } \\
\text { compliance }\end{array}$ & $\begin{array}{l}\text { Found that the coefficient for the cost of tax compliance } \\
\text { was }-.010 \text {, therefore there is a negative correlation occur } \\
\text { between the level of tax compliance and the cost of tax } \\
\text { compliance. }\end{array}$ & $\begin{array}{l}\text { Found that the coefficient for the cost of tax compliance } \\
\text { was } .083 \text { which means when increasing the cost of tax } \\
\text { compliance by one unit, which results in an increase in } \\
\text { the level of tax compliance by } .083 \text { So, exists a positive } \\
\text { relationship between each other. }\end{array}$ \\
\hline
\end{tabular}

\section{Conclusions}

This review paper illustrates different views held by various scholars in connection with tax compliance and its relationships with other variables with the aim of gaining new knowledge as well as broaden the knowledge base on this particular subject area ,which is important for any future researchers to identify the different concepts and their relative importance to the present context in Sri Lanka. Therefore, the conceptual ideas brought from this review paper will set a new direction for future research that will help to understand the significances of 
these conceptual ideas. If it makes sense in the future studies, then these concepts will apply to different practical situations in Sri Lanka as well as globally.

\section{References}

Ajzen, I., \& Fishbein, M. (1991). Theory of Planned Behavior: Organization behavior and human decision processes. Retrieved from https://www.sciencedirect.com/science/article/pii/074959789190020T

Alabede, J. O., Zaimah, Z. A., \& Kamil, M. I. (2011). Determinants of tax compliance behavior: An alternative model for Nigeria. International Research Journal of Finance and Economics, 78, 121-136. Retrieved from http://www.academia.edu/1424990/Determinants_of_Tax_Compliance_Behaviour_A_Proposed_Model_for Nigeria

Ali, Z. A. (2018). Tax evasion determinants in Banadir region, Somalia. Department of Accounting, Faculty of Business and Management, Simad University, Mogadishu, Somalia. Retrieved from https://jafas.org/articles/2019-5-1/3_FULL_TEXT.pdf

Allingham, M. G., \& Sandmo, A. (1972). Income tax evasion: A theoretical analysis. Journal of Public Economics, 323-338. Retrieved from http://www3.nccu.edu.tw/ klueng/tax\%20paper/1.pdf

Alm, J., Jackson, B., \& Mckee, M. (1992). Institutional uncertainty and taxpayer compliance. The American Economic Review, 82(4), 1018-1026. Retrieved from https://econpapers.repec.org/RePEc:aea:aecrev:v:82:y:1992:i:4:p:1018-26

Amjath, M. B. M. (2015). Tax evasion and non-compliance attitude of income taxpayers in Sri Lanka. Asia Pacific Journal of Research. Retrieved from http://ir.lib.seu.ac.lk/handle/123456789/1835

Anderhub, V., Giese, S., Giith, W., Hoffmann, A., \& Otto, T. (2001). Tax evasion with earned income: An experimental study. Finanz Archiv, 58(2), 188-206. Retrieved from https://www.jstor.org/stable/40912963

Andreoni, J., Erard, B., \& Feinstein, J. (1998). Tax compliance. Journal of Economic Literature, 16, 818-860. Retrieved from https://www.jstor.org/stable/2565123

Atawodi, O. W., \& Ojeka, S. A. (2012). Factors that affect tax compliance among SMEs in North Central Nigeria. International Journal of Business and Management, 7(12), 87. Retrieved from http://www.ccsenet.org/journal/index.php/ijbm/article/view/15251

Atawodi, O. W., \& Ojeka, S.A. (2012).Factors that influence tax compliance among Small and Medium Enterprises (SMEs) in North Central Nigeria. International Journal of Business and Management, 7(12), 88-96.

Retrieved

from https://www.researchgate.net/publication/266349181_Factors_That_Affect_Tax_Compliance_among_Smal 1_and_Med

Ayuba, A., Saad, N., \& Ariffin, Z. Z. (2016). Does perceived corruption moderate the relationship between economic factors and tax compliance marginally? A newly developed model for Nigerian Small and Medium Enterprises. Mediterranean Journal of Social Sciences, 7(1), 402-409. Retrieved from https://www.researchgate.net/publication/289365961_Does_Perceived_Corruption_Moderate_the_Relation ship_Betwe

Becker, G. S. (1968).Crime and punishment: An economic approach. Journal of Political Economy, 76(2), pp, 169-217.

Retrieved

from https://olis.leg.state.or.us/liz/2017R1/Downloads/CommitteeMeetingDocument/125036

Beesoon, D., Soondram, H. P., \& Jugurnath, B. (2016). Assessing the determinants of income tax compliance in Mauritius : A Study of Individual Taxpayers, fifth Asia-Pacific Conference on Global Business, Economics, Finance and Social Sciences (Ap16mauritius Conference). Retrieved from https://jafas.orgofrg/articles/2019-5-1/3_FULL_TEXT.pdf

Bernadette, K. (2010). Tax compliance of small business owners, International Journal of Entrepreneurial Behaviour, 18, 330-331. Retrieved from https://www.emeraldinsight.com/doi/abs/10.1108/13552551211227710

Carroll, E. (2011).Policy analyst views on Ghana's informal sector: The experience of women Christian aid $\begin{array}{lllll}\text { occasional. } & \text { Paper } & \text { No } & 7 . & \text { Retrieved }\end{array}$ https://www.christianaid.org.uk/sites/default/files/2017-08/taxing-ghana-informal-sector-november-2011.pd f 
Chebusit, C., Namusonge, G. S., Biraori, O. E., \& Kipkoech, E. C. (2014). Factors affecting tax compliance among small and medium enterprises in Kitale town Trans-Nzoia County, Kenya. Retrieved from http://www.paperpublications.org/download.php

Chipeta, C. (2002). The second economy and tax yield in Malawi, research paper No. 113. Retrieved from https://aercafrica.org/wp-content/uploads/2018/07/RP113.pdf

Clotfelter, C. (1983).Tax evasion and tax rates: An analysis of personal Returns. Review of Economics and Statistics, 65(3), 363-373. http://dx.doi.org/10.2307/1924181.

Collins, J. H., \& Plumlee, R. D. (1991). The taxpayer's labor and reporting decision: The effect of audit schemes. Accounting Review, 66(3), 559-576. Retrieved from https://www.jstor.org/stable/247809

Commissioner General of Inland Revenue. (2016). Sri Lanka annual performance report (pp. 19-20). Retrieved from http://www.ird.gov.lk/en/publications

Coolidge, J. (2010). Tax compliance cost reduction investigations: Using data to design targeted reforms. Retrieved from http://documents.worldbank.org/curated/en/371871468295501537/Tax-compliance-cost-surveys-using-data -to-design-targeted-reforms

Cowell, F. A., \& Gordon, J.P.F. (1988). Tax evasion and public good provision. Journal of Public Economics, 36, 305-321. http://journals.sagepub.com/doi/abs/10.1177/2321022218791010.

Economy Watch Dog. (2015). Tax burdens on SMEs in South Africa. Retrieved from http://ec.europe.eu/comm/entreprenuership/index.html

Emanuele, C. (2012). Economics of Taxation: Normative and positive theories. Hauppauge, NY, USA: Nova Science Publishers, Inc. Retrieved from http://erepository.uonbi.ac.ke/bitstream/handle/11295/95034/Musau_Determinants\%20of\%20tax\%20compl iance $\% 20$ among $\% 20$ Small $\% 20$ and $\% 20$ Medium $\% 20$ Enterprises $\% 20 \mathrm{in} \% 20$ Kenya.pdf? sequence=1\&isAllo wed $=\mathrm{y}$

Eragbhe, E., \& Modugu, K. P. (2014). Cost of tax compliance for Small and Medium Scale Enterprises in Nigeria. International Journal of Accounting and Taxation, 2(1), 63-87. Retrieved from http://ijatnet.com/journals/ijat/Vol_2_No_1_March_2014/5.pdf

Erten. (2002). An investigation of tax compliance intention: A theory of planned behavior. Retrieved from https://www.researchgate.net/publication/263199013_An_Investigation_of_Tax_Compliance_Intention_A_ Theory_of_Plan

Fehr, E., \& Rockenbach, B. (2003). Detrimental effects of sanctions on human altruism, in the incentive articles. Nature, $\quad 422, \quad 137-140 . \quad$ Retrieved from https://www.econ.uzh.ch/dam/jcr:ffffffff-9758-127f-ffff-fffff7a195d6/Detrimental_Effects_Original_Natur_ Version.pdf

Friedland, N., Maital, S., \& Rutenberg, A. (1978). A simulation studies on income tax evasion. Journal of Public $\begin{array}{llll}\text { Economics } & \text { 10(1), } & \text { Retrieved } & \text { from }\end{array}$ https://econpapers.repec.org/RePEc:eee:pubeco:v:10:y:1978:i:1:p:107-116

Garboua, L. L., Montmarquette, C., \& Masclet, D. (2006). A micro foundation for the Laffer curve in a real effort experiment, CIRANO working papers. Retrieved from https://ideas.repec.org/f/c/pma535.html

Geletaw, T. T. (2017). Taxpayers' tax compliance behavior: Corporate taxpayers of Addis Ababa City $\begin{array}{llll}\text { Administration. } & \text { Masters } & \text { Thesis, } & \text { Retrieved }\end{array}$ https://journals.abc.us.org/index.php/abcra/article/view/973

Hijattulah, A., \& Pope, J. (2008). Exploring the relationship between tax compliance cost and compliance issues in Malaysia. Journal Of Applied Law and Policy. Retrieved from https://espace.curtin.edu.au/handle/20.500.11937/23448

Institute of Policy Studies. (2015). Taxation impact on SMEs in Sri Lanka. Retrieved from http://www.dailymirror.lk/72317/new-ips-study-explores-taxationimpact-on-smes

Jayewardene, D., \& Low, K. (2016). Taxpayer attitude and tax compliance decision in Sri Lanka. International Journal of Arts \& Commerce, 5(2), 124-135. Retrieved from https://ijac.org.uk/images/frontImages/gallery/Vol._5_No._2/12._124-135.pdf 
Kariyoto, (2010). Effect of tax reform, tax audit, awareness and compliance taxpayers against taxation performance. Unpublished Dissertation. Brawijaya University. Retrieved from https://academicjournals.org/journal/JAT/article-full-text-pdf/F1DD78E66686

Kirchler, E., Hoelzl, E., \& Wahl, I. (2008). Enforced versus voluntary tax compliance: The slippery slope framework. Journal of Economic Psychology, 29, 210-225. Retrieved from https://www.sciencedirect.com/science/article/pii/S016748700700044X

Kogler, C., Mittone, L., \& Kirchler, E. (2016). Delayed feedback on tax audits affects compliance and fairness perceptions. Journal of Economic Behavior \& Organization 124(c), 81-87. Retrieved from https://ideas.repec.org/a/eee/jeborg/v124y2016icp81-87.html

Krause, K. (2000). Tax complexity: Problem or Opportunity? Public Finance Review, 395-414. https://journals.sagepub.com/doi/abs/10.1177/109114210002800501

Laksono, J. P., \& Ardiyanto, M. D. (2007). Analysis of factors affecting taxpayer compliance in manufacturing industrial company in Semarang. https://academicjournals.org/journal/JAT/article-references/F1DD78E66686

Lediga, C., Riedel, N., \& Strohmaier, K. (2018). Combatting tax evasion: Evidence from comparing commercial and business tax registry. CESifo working papers 7117. Retrieved from https://www.ifo.de/DocDL/cesifo1_wp7117.pdf

Levi, M. (1988). Of rule and revenue: University of California Press. Retrieved from https://scholar.princeton.edu/sites/default/files/tpavone/files/margaret_levi-of_rule_and_revenue_summary. pdf

Loo, E. C., McKerchar, M., \& Hansford, A. (2008). Tax compliance behavior: Findings derived from a combined method design. Paper submitted at the 8th International Tax Administration Conference, Sydney, Australia. Retrieved from http://www.journalcra.com/sites/default/files/issue-pdf/26688.pdf

Marshall, R. L., Robert, W. A., \& Smith, M. (1998).The ethical environment of tax practitioners: Western Australian evidence. Journal of Business Ethics, 17, 1265-1279. Retrieved from https://link.springer.com/article/10.1023/A:1005721505618

Marziana, H. M., Norhafizah, A., \& Mohamad, S. D. N. (2010). Perceptions of taxpayers with the level of compliance: A comparison in the East coast region, Malaysia. Journal of Global Business and Economics, 1(1), 241-257. Retrieved from https://www.researchgate.net/profile/Mohd_Fuad_Salleh/publication/313880627_The_Determinants_of_In dividual_Taxpay

Mas'ud, A., Aliyu, A. A., \& Gambo, E. J. (2014).Tax rate and tax compliance in Africa. European Journal of Accounting Auditing and Finance Research, 2(3), 22-30. Retrieved from https://pdfs.semanticscholar.org/c422/7b8044522d6318333f01e30a0dc3cf630052.pdf

McBarnet, D. (2003). When compliance is not the Solution but the Problem: from changes in the law to changes in attitude, Bibliography. $\quad$ Retrieved from https://www.academia.edu/540974/A_GENERAL_THEORY_OF_TAX_LAW._DISTRIBUTIVE_JUSTIC E_LAW_AND_LE

McGee, R. W. (2006). Three views on the ethics of tax evasion. Journal of Business Ethics. Retrieved from https://link.springer.com/article/10.1007/s10551-006-9002-z

McKerchar, M. (1995). Understanding small business taxpayers, their sources of information and level of knowledge of taxation. Australian Tax Forum, 12(1), 25-41. Retrieved from https://www.researchgate.net/publication/270848010_Tax_Knowledge_Tax_Complexity_and_Tax_Compli ance_Taxpayers'_V

Mehari, D., Abdulmajeeb, \& Pasha. (2017). Factors affecting voluntary compliance of taxpayers: Attitude Of Arbaminch, SNNPR, Ethiopia. International Journal of Scientific and Research Publications, 7(6), 48-63. Retrieved from Http://Www.Ijsrp.Org/Research-Paper-0617/Ijsrp-P6609.Pdf.

Mocetti, S., \& Barone, G. (2008). Tax morale and public spending inefficiency. International Tax and Public Finance, 18(6). Retrieved from http://www.siepweb.it/siep/oldDoc/2008/200822.pdf

Moore, M. (2004). Revenues, state formation, and the quality of governance in developing countries. International Political Science Review, 25(3), pp, 297-319.Retrieved from 
http://www2.ids.ac.uk/gdr/cfs/pdfs/Moore\%20International\%20political\%20science\%20review\%20article $\% 202004 . p d f$

Munari, A. (2005).Influence success factors against taxpayer acceptance of income tax (KPP Case Study Batu, Malang). $\quad$ Executive $\quad J . \quad 2(2): \quad 120-124 . \quad$ Retrieved from https://academicjournals.org/journal/JAT/article-references/F1DD78E66686

Murphy, K., \& Harris, N. (2007). Shaming, shame, and recidivism: A test of reintegrative shaming theory in the white-collar crime context. British Journal of Criminology, 47, 900-917. Retrieved from https://psycnet.apa.org/record/2007-16615-004

Nahida, F., Copp, R., Freudenberg, B., \& Sarker, T. (2014). Complexity, compliance costs and non-compliance with VAT by Small and Medium Enterprises (SMEs) in Bangladesh: Is there a Relationship? Griffith University. $\quad$ Retrieved from https://www120.secure.griffith.edu.au/rch/file/1fb8d772-caff-471f-83e8-87ce375acab9/1/Faridy_2016_01T hesis.pdf

Organization for Economic Cooperation and Development. (2014). Basic principles of taxation: Addressing the tax challenges of the digital economy. https://www.oecd.org/ctp/addressing-the-tax-challenges-of-the-digital-economy-9789264218789-en.htm

Osebe, R. P. (2013). An analysis of factors affecting tax compliance in the real estate sector in Kenya: A Case of real estate owners in Nakuru town. Unpublished project report, Kabarak University, Kenya. Retrieved from https://www.iiste.org/Journals/index.php/RJFA/article/download/13523/14240

Owens, J., \& Hamilton, S. (2004). Experience and innovations in other countries: The crisis in tax administration (pp. 201-229). Washington DC: Brookings Institution Press. Retrieved from http://www.seap.usv.ro/annals/ojs/index.php/annals/article/viewFile/473/466

Palil, M. R.(2010). Effect of the current law in Kenya on the tax compliance of SMEs in the Nairobi North tax region. Retrieved from https://pdfs.semanticscholar.org.

Persson, A. (2008). The institutional sources of statehood - assimilation, multiculturalism, and taxation in SubSaharan Africa, doctoral thesis, Gothenburg University. Retrieved from https://gupea.ub.gu.se/bitstream/2077/17291/3/gupea_2077_17291_3.pdf

Porschke, C., \& Erich, H. W. (2002). Psychologische faktoren der steuergerechtigkeit, wirtschaftspsychologie. Retrieved from https://www.ssoar.info/ssoar/handle/document/39993

Pratama, M. R. (2012). Analisis faktor - faktor yang mempengaruhi kesadaran wajib pajak orang pribadi terhadap kepatuhan kewajiban perpajakan di kota tangerang selatan. Thesis. Bina Nusantara University, Jakarta. Retrieved from https://academicjournals.org/journal/JAT/article-references/F1DD78E66686

Rachman, F. F. (2017). Sri Mulyani: Setoran pajak rendah sekali, tak bisa diterima. Retrieved from https://finance.detik.com/berita-ekonomi-bisnis/d-3557665/sri-mulyani-setoran-pajak-rendah-sekali-tak-bis a-diterima

Saad, N., Mansor, M., \& Ibrahim, I. (2003). The self-assessment system and its compliance costs. Paper presented at the accounting seminar, Malaysia. Retrieved from https:/www.sciencedirect.com/science/article/pii/S1877042813052294

Sandmo, A., \& Allingham, M. G. (1972). Income tax evasion: A theoretical analysis. Journal of Public Economics, 1, 323-338. Retrieved from http:/www3.nccu.edu.tw/ klueng/tax\%20paper/1.pdf

Santoso, W. (2008). Failure risk analysis as the basis for increased taxpayer compliance. Journal of Accounting and Taxation, 5(1), 85-137. $\quad$ Retrieved from https://academicjournals.org/journal/JAT/article-references/F1DD78E66686

Sapiei, N. S., \& Kasipillai, J. (2013). Taxpayer compliance behavior of corporate taxpayers. American Journal of Economics, $\quad 3(2), \quad 82-89 . \quad$ Retrieved from https://pdfs.semanticscholar.org/d61e/a4e4e444cabc05790e507ccb31645d143b37.pdf

Sawitri, A. A. (2017). Sri mulyani paparkan hasil kerja tim reformasi pajak. Retrieved from https://www.seekdl.org/conferences/file/paper/20180822_105508.pdf

Schmölders, G. (1960). Das Irrational in der öffentlichen Finanzwirtschaft,Frankfurt. National Tax Journal, 12, 340-345. Retrieved from https://link.springer.com/chapter/10.1057/9780230625112_1 
Sjursen, I. H., Ali, N., \& Helge, O. F. (2014). To attitudes toward taxation in Kenya, Tanzania, Uganda, and South Africa. Retrieved from https://academicjournals.org/journal/JAT/article-references/F1DD78E66686

Song, Y. D., \& Yarbrough, T. E. (1978).Tax ethics and taxpayer attitudes: A survey. Public Administration Review, 38(5), 442-452. Retrieved from https://www.scribd.com/document/378258366/Ethics-and-Attitudes

Spicer, M. W., \& Lundstedt, S. B. (1976). Understanding tax evasion. Public Finance, 31(2), 295-305. Retrieved from

https://books.google.lk/books?id=yg5jDwAAQBAJ\&pg=PA55\&lpg=PA55\&dq=Spicer,+Michael+W.+and + Sven + B. + Lundstedt $+(1976)+\%$ E $\% 80 \% 9$ EUnderstanding + tax + evasion $\%$ E2\% $\% 0 \% 9 F,+$ Public + Finance +2 1(2):\&source=bl\&ots=1fc_ToAXdc\&sig=ACfU3U1YV17aNgwpiikmj19GdJNZ_DpGkQ\&hl=en\&sa=X\&v ed=2ahUKEwi9le_J19LjAhW5ILcAHb5BDwEQ6AEwAHoECAkQAQ

Tilly, C. (1992). Coercion, capital, and European states: AD 1990-1992, Malden, Massachusetts, Blackwell Publishers Inc. Retrieved

from https://en.wikipedia.org/wiki/Coercion,_Capital,_and_European_States,_AD_990\%E2\%80\%931992

Torgler, B. (2005). Tax morale in Latin America. Public Choice, 122, 133-157. Retrieved from https://econpapers.repec.org/RePEc:kap:pubcho:v:122:y:2005:i:1:p:133-157

Troiano, U. (2017). Intergovernmental cooperation and tax enforcement. NBER working paper No. 24153, Cambridge, MA: National Bureau of Economic Research. Retrieved from http://www.nber.org/papers/w24153

Tyler, T. R. (2006). Psychological perspectives on legitimacy and legitimation: Annual Review of Psychology, https://www.annualreviews.org/doi/abs/10.1146/annurev.psych.57.102904.190038

Vihanto. (2000). Tax evasion and the psychology of humans. Journal of Behavioral and Experimental Economics, $\quad 32(2), \quad 111-125 . \quad$ Retrieved from https://pdfs.semanticscholar.org/3d0a/6496aaacbda34b35ed00c0a8d4504c465bab.pdf

Walsh, K. (2012). Understanding taxpayer behavior-new opportunities for tax administration. The Economic and Social Review, 43(3), 469-470. Retrieved from https://www.academia.edu/28583980/Review_of_Models_Theories_Explaining_Tax_Compliance_Behavio r

Waweru, M. G. (2004). Tax administration reforms in Kenya: Problems and Prospects. AGM of FKE. Retrieved from

http://erepository.uonbi.ac.ke/bitstream/handle/11295/94666/Gichuki\%20Evanson\%20Njaramba_Tax\%20a dministration

Yunus, N., Ramli, R., \& Syuhada, N. (2017). Tax penalties and tax compliance of Small Medium Enterprises (SMEs) in Malaysia. International Journal of Business, Economics, and Law, 12(1), 81-91.Retrieved from https://www.ijbel.com/wp-content/uploads/2017/07/ACC-342.pdf

Zulaikha \& Nugroho, R. A. (2012). Knowledge and understanding of the taxpayers: A good perception of the effectiveness of the taxation system and service quality. Diponegoro J. Account. 1:2. Retrieved from https://academicjournals.org/journal/JAT/article-references/F1DD78E66686

\section{Copyrights}

Copyright for this article is retained by the author(s), with first publication rights granted to the journal.

This is an open-access article distributed under the terms and conditions of the Creative Commons Attribution license (http://creativecommons.org/licenses/by/4.0/). 